\title{
Students' Perspectives on Speaking Anxiety in the English Foreign Language Classroom
}

\author{
Aulia Nisa Khusnia \\ University of Muhammadiyah Purwokerto \\ aulianisakhusnia.ma@gmail.com
}

\begin{abstract}
Anxious students are often concerned about the impressions that others form of them. When such students are confronted in a classroom with a learning situation that makes them uncomfortable, they may choose to withdraw from the activity. Some learners believe they cannot perform in English and consequently form negative expectations, which in turn lead to decreased effort and the avoidance of opportunities to enhance their communication skills. The goal of this study was to identify those factors, as perceived by students, that may contribute to anxiety, and those factors that may reduce anxiety in an attempt to understand more fully the role that anxiety may play in learning a foreign language.
\end{abstract}

Keywords: students' perspective, speaking anxiety, english foreign language classroom

\section{Introduction}

Many of us have been in situations as language learners when we are asked a question and our minds mysteriously go blank. Or perhaps our heads follow a teacher around the class as we nervously await our turn to speak, barely listening to other students' output, our eyes trained on the teacher to see which "unfortunate victim" will be chosen to speak next. At other times we shun communicative opportunities altogether. While some students avoid talking because they are unprepared, uninterested, or unwilling to express themselves, most anxiety stems from feelings of alienation in class, from a lack of confidence, or because the students fear communication itself (Daly, 1991). Reflecting on my own, anxiety-ridden experiences of learning foreign language, I pondered that if my English conversation classes somehow induce anxiety and lead to a miserable experience, then I need to consider how to encourage my own students in their English study.

Task-based language teaching often utilizes incongruity and unpredictable learning activities to encourage communication (Ellis, 2003). Arguably, tasks that are not focused in a sequence of activities that ends with controlled practice may unwittingly encourage anxiety. As Aida (1994) notes, many language teachers are concerned about the possibility that anxiety may function as an affective filter preventing learners from achieving a high level

Students' Perspectives on Speaking Anxiety in The English Foreign Language 41 Classroom 
of proficiency in the language. Learners need to have attitudes and use strategies that encourage lowered anxiety, higher motivation, and confidence in their ability to convey what they want to say. One of the challenges for teachers is to provide the kind of classroom atmosphere that promotes lowanxiety.

Nespor (1987) writes that beliefs are "composed of episodically stored material derived from personal experience" (p. 320) which derive legitimacy from past episodes. These critical episodes then "color or frame the comprehension of events later in time" (ibid.). Thus, learners' experiences determine the value of similar, but new, tasks. In the classroom, students perform a "cognitive appraisal" (Dayhoff, 2000, p.15) which helps affect judgments. Students who experience anxiety in the classroom often base their fear on an inaccurate assessment of its causes. They imagine danger where it does not necessarily exist and do not have an effective plan of action to cope with their anxiety. Over time and in different learning situations people develop expectations concerning the likely outcomes of various behaviors within and across situations, but when they engage in communicative behaviors that seem to work, they develop positive expectations for those behaviors, and these can become a regular part of learners' communicative repertoire.

However, if experiences are negative, language anxiety begins to develop and if these negatively perceived experiences continue, foreign language anxiety may become a regular occurrence and the learner begins to routinely expect to be nervous and perform poorly. Anxiety can be associated with a variety of physiological and emotional states, embodied in feelings of tension even in situations where the immediate cause of such tension is not readily apparent.

Anxiety is related to self-focused, negative and anxious cognition during interaction. Highly anxious students often have relatively negative selfconcepts, underestimating the quality of their speaking ability when compared with others. While some may argue that a dose of anxiety is necessary to create a language learning "charge", for many students nervousness distracts from attending to and remembering new language, and will thus affect the practice required for language to be assimilated.

An unwillingness to make an effort can be seen as debilitating in communicative language classrooms, where making an attempt to use new language forms is a central tenet of second language acquisition. This unwillingness may spark what Dayhof (2000) calls the "anxiety feedback loop" (p.27), in which anxiety is triggered by concern over being scrutinized and evaluated by others in a performance situation. This can lead to an excessive fear of being humiliated or judged negatively in learning situations. Yet, I contend that students can make their learning more profitable and less painful by reflecting on their learning experiences and receiving necessary guidance.

\section{Methods}

The primary goal of this research was to identify those factors, as

Students' Perspectives on Speaking Anxiety in The English Foreign Language 42 Classroom 
perceived by students, that may contribute to anxiety, and those factors that may reduce anxiety in an attempt to understand more fully the role that anxiety may play in learning a foreign language.

This study utilized the qualitative research tradition, the phenomenological interview (LeCompte \& Preissle, 1993; Rubin \& Rubin, 1995), with the inclusion of a quantitative component. Attention was focused on the participants' beliefs, experiences, and feelings in order to generate an enlightening narration of the participants' perspectives of foreign language anxiety. The qualitative approach allows the researcher to capture the students' own voices and to examine their words and beliefs in an attempt to understand the phenomenon and to answer these basic research questions:

1. Do students believe that anxiety hinders language acquisition?

2. Which factors do students believe contribute to anxiety?

3. Which factors do students believe may help to reduce anxiety?

4. How is anxiety manifested in the students?

5. Do students believe any one of the three languages being investigated to be more anxiety provoking than another?

A general interview guide was followed, using this set of questions that were developed to elicit answers without limiting or inhibiting the respondents.

1. Please describe your feelings about your foreign language class.

2. Please tell me what you like best about your foreign language class.

3. Please tell me what disturbs you the most in your foreign language class.

4. Are there other things that disturb you about your foreign language class that you can tell me, and how do you react to them?

5 . Do you believe that you are good in your language study (that is, are you confident of your ability)?

6 . How do you think people in your classroom will react if you make mistakes?

7. When you find yourself in a stressful situation, do you primarily worry, or do you actively seek a solution?

8. Have your instructors played a role in your feelings, either good or bad, about your foreign language classes?

9. Do you have any ideas of ways to make the foreign language class less stressful?

10. How do you feel now after addressing this issue?

The answers provided rich detail used in answering the basic research questions. Interview questions 5,6 , and 7 were specifically formulated to elicit information regarding student beliefs concerning ability and contexts. That is, are students "ruminating about causes and feelings" (Ford, 1992, p. 113) or do they take action to "solve a problem or reduce feelings of distress" (p. 113)? Question 10 was included in an attempt to understand if the students may have learned more about foreign language anxiety or might have benefited otherwise from their participation in the study. 
The taped interviews were transcribed verbatim by the researcher. The transcriptions of the interviews were analyzed according to basic categories developed from the interview questions: factors believed to cause anxiety, factors believed to reduce anxiety, manifestations of anxiety, student awareness of anxiety, and most anxiety provoking language. Under each separate category, portions of dialogue were detailed according to individual participant response. In this way the source of the quotation was readily identifiable. The factors were then extrapolated from the dialogue portions and listed. Where appropriate, subcategories were also developed. Concomitantly, the transcriptions were analyzed to seek out commonalties and patterns emerging from other interview questions. The qualitative narrative was generated from these data.

The participants were eager to talk. Each had a story to tell that often became a diatribe against a particular teacher or methodology. It was somewhat of a surprise to this researcher to hear how vivid and explicit the memories of painful or exasperating situations were, even though Price (1991) had reported similar findings. Some of these negative experiences originated in high school classes, and for many this emotional baggage seemed to intrude into their current study.

\section{Findings}

The interviews revealed extremely negative experiences with the language class. When asked to describe their feelings several students provided examples of how anxiety can lead to frustration and even anger. These interviews presented the students with an opportunity not only to express their problems and concerns, but allowed them to vent much of their frustration. With the exception of the most highly anxious student who said that nothing helped her, most of the students reported positive benefits from their participation in this research. Several appeared relieved to learn that they were not alone in their anxieties.

For example, one student revealed, "at first, I thought my God, am I the only one who's getting nervous, the only one whose heart is beating, like pounding really hard? But now, I know I'm not the only one." Foss and Reitzel (1988) also found that anxiety was reduced for many students merely by knowing that they were not alone in their fears or beliefs.

\section{Discussion}

\section{The Research Questions}

\section{Do students believe that anxiety hinders language acquisition?}

Some students were unaware of foreign language anxiety, others were unsure, but still conscious of a generalized feeling of uneasiness. Other students appeared to use the terms frustration, nervous, and anxious interchangeably. One student seemed to equate getting angry with being anxious. He mentioned that he got so frustrated that he wanted to break the desk.

\section{Which factors do students believe contribute to anxiety?}

Students' Perspectives on Speaking Anxiety in The English Foreign Language 44 Classroom 
The participants cited numerous and various sources for their anxiety, such as speaking activities, inability to comprehend, negative classroom experiences, fear of negative evaluation, native speakers, methodology, pedagogical practices, and the teachers themselves. The sources of anxiety often were intertwined, causing difficulty in teasing out a discrete factor or source. The following discusses the most frequently cited anxiety-generating factors.

Non-Comprehension. The inability to comprehend what was being said in the classroom provoked considerable anxiety. Many complained that the teacher spoke much too fast, or refused to use any English at all which resulted in an inability to keep up during class, and consequently carried over into the homework assignments. Young (1992) also noted that listening might generate anxiety if it were "incomprehensible" (p.68). The inability to comprehend the taped exercises or the instructional videos was also cited as anxiety- provoking by several students. One student reported nervousness even before the taped dictation just looking at the machine.

Speaking activities. Many of the anxiety-provoking factors reported by the participants appeared to be generated by various speaking activities normally encountered in a language class. The fear of communicating orally and public speaking anxiety have long been accepted psychological phenomena. Daly (1991) noted that the fear of giving a speech in public exceeded even such phobias as fear of snakes, elevators, and heights. Whereas those with public speaking concerns have only to perform, language learners have a dual task. They must not only learn the new language but perform in it as well (Foss \& Reitzel, 1988). One student of Spanish complained, "I don't want to be the focus of attention so that my errors are put on display." Horwitz, Horwitz and Cope (1986) reported that students are very self-conscious when they are required to engage in speaking activities that expose their inadequacies, and these feelings often lead to "fear, or even panic" (p. 128). As expected, the participants were sensitive to both peer and teacher evaluation of their speaking. Additionally, a few seemed to project negative thoughts on to the teacher. One highly anxious student reported feelings of frustration that the teacher thought she didn't know anything when she really did.

Students also report feeling overwhelmed and anxious when speaking, perhaps due to an immature vocabulary or limited grammatical knowledge. One frequently cited anxiety-provoking factor in the interviews was simply being called on in class, whether prepared or not.

Pedagogical and instructional practices. Test anxiety was mentioned during the interviews, particularly in connection with oral testing or listening exercises. One student admitted at being near tears during the final exam when he had to give an oral presentation, and was upset, shaking and sweating.

Several students were concerned that the language class moved so quickly that they did not have sufficient time to digest the rules and vocabulary. A few commented that the amount of material to be covered in

Students' Perspectives on Speaking Anxiety in The English Foreign Language 45 Classroom 
one semester was excessive, remarking "all of the more advanced grammar came in one semester and it wasn't enough time to absorb it." Several other students made comments regarding the "speed" of the course and complained that teachers "just keep on going" and do not layer and reinforce the grammar items. An extremely anxiety-provoking technique, and one used by most foreign language teachers, is calling on students one after another in seating order. The most explicit description of this technique was given by a student who said, "I think that builds tension, builds anxiety, just sitting there knowing that in a few minutes you're about to be called, and it's almost execution style." Other students voiced similar concerns regarding this practice and used words like "stupid," "idiot," and "torture" in their descriptions.

The pedagogical practice and teacher idiosyncrasies were quite often inextricably bound. The most disturbing aspect of the class, according to many students, was directly related to the teachers themselves; that "the teacher was trying to make you feel stupid," and this indicated a lack of respect on the part of the teacher. An astonishing numbert of negative comments were made regarding the teachers, such as "very intimidating," "apathetic," "condescending," "a nasty person," "very stern and mean almost and so she scared me," and even "obnoxious." One caution: This is a small sample (15) of students who perceived themselves to be anxious in foreign language class for any number of reasons, and were offered an opportunity to have their voices heard. There was no intention to indict teachers, merely to report the factors cited by this particular sample as anxiety-provoking. Some students reported instances where the teacher had either humiliated them or made them feel very uncomfortable. A student of German expressed her feeling about the importance of the teacher stating, "the instructor will either make or break the course, that's how I look at it."

Error correction. Another pedagogical practice cited as anxietyprovoking by the participants concerned error correction. One student reported being disturbed when teachers "begin to reprimand" students for making errors. Students reported becoming frustrated when the teacher would correct the error before they had time to completely formulate a response. Comments made by several students pertained to teachers interrupting to correct speaking errors. These interruptions would frequently cause students to lose their focus.

Native Speakers. Another anxiety-provoking factor cited by many participants concerned native speakers in the classroom. This appeared to be a problem mainly in Spanish classes, but was also mentioned by one student of French. Some students believed that the teachers somehow taught to the higher level, or deferred to the native speakers in some way. The students seemed to have a perception of being compared negatively to the native speakers.

Which factors do students believe may help to reduce anxiety?

Clearly, for these students, foreign language classes generated considerable anxiety. Therefore, it was anticipated that the students 
themselves would offer concrete suggestions for alleviating this anxiety, which they did. The proposals ranged from simple suggestions to complex curriculum and textbook changes.

A sense of community. One common thread running through the responses was that of communality or connectedness. It was suggested that students be encouraged to get together outside the classroom and know each other personally. When students felt alone with no friends, they were "more self-conscious." A lunch group was suggested as one way for students to interact, and several participants mentioned working in groups or having study partners. Properly structured, group work and study groups appear to reduce anxiety for some.

Pedagogical practices and classroom environment. The desire for a feeling of community was also reflected in suggestions regarding seating in the class. Suggestions were made that the students should sit in a semicircle or oval because "in a circle you're kind of like one in a crowd." The participants named having a relaxed classroom environment as paramount in reducing anxiety. It appears that a relaxed environment or atmosphere is likely related to how the teacher conducted the class.. The participants were quite clear in noting the connection between anxiety and teacher behavior. Several students mentioned that having a more "personal relationship" with the teacher was helpful. The teacher's attitude toward the language itself also appeared to play a role in reducing anxiety. For example, one student reported that "personality is what makes the class."

Similarly, the students reported that they were less anxious with teachers who "made the class fun," "made it fun to like learning," or "makes the class more animated," and with "teachers who make it interesting by using interesting situations."

The majority of students mentioned that "not being put on the spot" in class would help them to be less anxious. When asked to explain, one student said, "Um, I guess not just abruptly calling on someone." Another responded, that being "put on the spot" would "let everyone stare, which makes everything worse." As several students pointed out, gentle error correction or modeling the correct response "helps to relieve anxiety."

Some classroom activities named as anxiety-reducing were skits, plays, and games. However, it should be noted that some students are uncomfortable in these kinds of activities. Several students mentioned that they might feel more comfortable if the instructional material were more relevant to their life or goals. One student suggested that the teacher do a short presentation on anxiety the first day of class to let people know that it is a common problem. The results of this study also suggest that a targetlanguage-only approach may be distressing for lower level students without some English reference points. Nearly all the participants offered three other suggestions: 1) speak slowly, 2) use English to clarify key points and for homework assignments, 3) to make sure that everyone understands by a continuous layering and reinforcing of the material. Other than use of videos, error correction, excessive homework assignments, and immersion 
techniques, only two participants articulated clear references to instructional materials and methodology.

Role of teacher. These interviews suggest that the role of the teacher is paramount in alleviating anxiety, more vital perhaps than a particular methodology. Teachers who provide a supportive and understanding environment, who employ nonthreatening teaching methods, and who use appealing and relevant topics seem to enhance the foreign language experience. These findings were congruent with those of Price (1991) who reports that her research clearly showed that "instructors had played a significant role in the amount of anxiety each student had experienced in particular classes" (p. 106) as well as that of Young (1990) who noted that anxiety decreased when instructors "create a warm social environment" ( $p$. 550). The interviews also indicate that an atmosphere of cordiality, communality, and friendship among the students themselves appears to ease learner anxiety. Samimy and Rardin (1994) also reported that group solidarity seems to lighten emotional barriers like anxiety and may intensify language learning.

How is anxiety manifested in the students?

Physical. Some of the physical symptoms include "headaches"; "clammy hands, cold fingers"; "shaking, sweating"; "pounding heart"; "tears"; "foot tapping, desk drumming"; "I clamp up, I get very tense and I start balling my fists"; "my stomach gets in knots"; "I get all red"; and "I get really tired." One student would hunch over her desk in a kind of protective shell. Another student reported similar behavior: "I kind of turtle up and hide from the teacher." Hiding from the teacher in one way or another was a common manifestation of anxiety.

Internal and functional. Students mentioned that they projected their nervousness days in advance of the class, thus affecting classroom performance. A student of French reported that in class, "I just completely blank out and everything is like a jumble in my head." Other participants reported more subtle or internalized manifestations. A student of French described her reaction as internal as though "the time bomb was ticking in here," and that she was "petrified in that class, just totally petrified." Some students said they reacted by losing patience or becoming angry. One thought he projected his anger over a former French teacher on to his present German teacher. The almost compulsive need to look ahead in the book was not uncommon among these participants. One student said that she became aware of other students' anxiety when "people start flipping through the book, they don't know."

Avoidance. Avoidance was another fairly common manifestation of anxiety; "oftentimes people will begin to not show up to class." Other students practiced a more subtle form of avoidance. One student of French said that he wrote in his book, drew pictures in it, or organized his date planner during class. One student reported a rather extreme form of classroom avoidance, "I've seen people just go right to sleep."

Do students believe any one of the three languages being investigated to be

Students' Perspectives on Speaking Anxiety in The English Foreign Language 48 Classroom 


\section{more anxiety provoking than another?}

The majority of participants had experience with more than one language and appeared to equate difficulty with anxiety. The perception that a language is difficult seems to suggest that it is also anxiety-provoking. Often when the participants attempted to cite an anxiety-provoking language, they equivocated, gave ambiguous answers, or offered elaborate reasons for their choice.

\section{Conclusion}

The findings of this study appear to corroborate other studies in suggesting that anxiety can negatively affect the language learning experience in numerous ways and that reducing anxiety seems to increase language acquisition, retention, and learner motivation. Therefore, it is suggested that awareness of foreign language anxiety be heightened and taken seriously by teachers and students alike. This may be accomplished by means of workshops or presentations elaborating foreign language anxiety and exploring the positive motivational aspects of anxiety reduction. It may also be helpful for teachers to become familiar with the FLCAS instrument (Horwitz, Horwitz \& Cope, 1986) to better understand the many ways in which students experience anxiety. Recommendations suggested by this study are that teachers strive to:

- create a low stress, friendly and supportive learning environment;

- foster a proactive role on the part of the students themselves to create an atmosphere of group solidarity and support;

- be sensitive to students' fears and insecurities and help them to confront those fears;

- use gentle or non-threatening methods of error correction and offer words of encouragement;

- make judicious use of purposeful group work or collaborative activities;

- use relevant and interesting topics for class discussions and exercises;

- consider decreasing the amount of new material to be covered in one semester;

- consider ways to layer and reinforce the material in an attempt to aid acquisition and retention;

- give written directions for homework assignments;

- speak more slowly or consider using English to clarify key points or give specific directions;

- attend to the learning styles or preferences of the students; and

- hear and appreciate the voices of students for valuable insights, ideas and suggestions.

One further research topic might be to attempt to determine if anxiety levels decrease as exposure to the language increases. Two measures of exposure may be investigated; the amount of time the language has been studied or by time spent in the target country, such as visits or semesters abroad. 


\section{References}

Aida, Y. (1994). Examination of Horwitz, Horwitz, and Cope's construct of foreign language anxiety: The case of students of Japanese. The Modern Language Journal, 78, 155-167.

Bailey, K.M. (1983). Competitiveness and anxiety in adult second language learning: Looking at and through the diary studies. In H.W. Seliger and M.H. Long (Eds.), Classroom oriented research in second language acquisition. Rowley, MA: Newbury House.

Campbell, C. M., \& Ortiz, J. A. (1991). Helping students overcome foreign language anxiety: A foreign language anxiety workshop. In E. K. Horwitz \& D. J. Young (Eds.), Language anxiety: From theory and research to classroom implications (pp.153-168). Englewood Cliffs, NJ: Prentice-Hall.

Crookall, D., \& Oxford, R. (1991). Dealing with anxiety: Some practical activities for language learners and teacher trainees. In E. K. Horwitz \& D. J. Young (Eds.), Language anxiety: From theory and research to classroom implications (pp.141-150). Englewood Cliffs, NJ: Prentice-Hall.

Daly, J.A. (1991). Understanding communication apprehension: An introduction for language educators. In E.K. Horwitz \& D. J. Young (Eds.), Language Anxiety: From theory and research to classroom implications (pp. 3-13). Englewood Cliffs, NJ: Prentice Hall.

Ely, C. M. (1986). An analysis of discomfort, risktaking, sociability, and motivation in the L2 classroom. Language Learning, 36, 1-25.

Ford, M. E. (1992). Motivating humans: Goals, emotions, and personal agency beliefs. Newbury Park, CA: Sage Publications.

Foss, K. A., \& Reitzel, A. C. (1988). A relational model for managing second language anxiety. TESOL Quarterly, 20, 559-562.

Ganschow, L., \& Sparks, R. L. (1996). Anxiety about foreign language learning among high school women. The Modern Language Journal, 80, 199-212.

Gillette, B. (1994). The role of learner goals in L2 success. In J. Lantolf \& G. Appel (Eds.), Vygotskian approaches to second language research. (pp. 195-213). Norwood, New Jersey: Ablex Publishing Corporation.

Horwitz, E. K., Horwitz, M. B., \& Cope J. (1986). Foreign language classroom anxiety. The Modern Language Journal, 70, 125-132.

Horwitz, E. K. \& , Young, D. J. (Eds.). (1991). Language anxiety: From theory and research to classroom implications. Englewood Cliffs, NJ: Prentice Hall.

Koch, A. S., \& Terrell, T. D. (1991). Affective reactions of foreign language students to Natural Approach activities and teaching techniques. In E. K. Horwitz \& D. J. Young (Eds.), Language anxiety: From theory and research to classroom implications (pp.109-126). Englewood Cliffs, NJ Prentice-Hall.

Krashen, S. D. (1985a). Applications of psycholinguistic research to the classroom. In C. James (Ed.), Practical applications of research in foreign language teaching (pp.51-66). Lincolnwood, IL: National Textbook Co.

Krashen, S. D. (1985b). The input hypothesis: Issues and implications. New York: Longman 
LeCompte, M. D., \& Preissle, J. (with Tesch, R.). (1993). Ethnography and qualitative design in educational research (2nd ed.). San Diego: Academic Press.

MacIntyre, P. D. (1995). How does anxiety affect second language Learning? A reply to Sparks and Ganschow. The Modern Language Journal, 79, 9199.

MacIntyre, P. D., \& Gardner, R. C. (1988). The measurement of anxiety and applications to second language learning: An annotated bibliography (Research Bulletin No. 672). London, Ontario: The University of Western Ontario. (ERIC Document Reproduction Service No. FL017649).

MacIntyre, P. D., \& Gardner, R. C. (1989). Anxiety and second language learning: Toward a theoretical clarification. Language Learning, 39, 251275.

MacIntyre, P. D, \& Gardner, R. C. (1991). Methods and results in the study of anxiety and language learning: A review of the literature. Language Learning 41, 85-117.

Trylong, V. L. (1987). Aptitude, attitude, and anxiety: A study of their relationships to achievement in the foreign language classroom (Doctoral dissertation, Purdue University, 1987). Dissertation Abstracts International, 48-10A, 2564.

von Wörde, R. A. (1998), An investigation of students' perceptions of foreign language anxiety (Doctoraldissertation, George Mason University, 1998). Dissertation Abstracts International, 59-03A, 0717.

Young, D. J. (1990). An investigation of students' perspectives on anxiety and speaking. Foreign Language Annals, 23, 539-553.

Young, D. J. (1991). Creating a low-anxiety classroom environment: What does language anxiety research suggest? The Modern Language Journal $75,426-439$.

Young, D. J. (1992). Language anxiety from the foreign language specialist's perspective: Interviews with Krashen, Omaggio Hadley, Terrell, and Rardin. Foreign Language Annals 25, 157-172. 